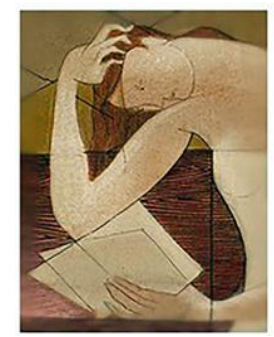

\title{
A malungaje poética de Oliveira Silveira
}

\section{Oliveira Silveira's poetical malungaje}

\author{
Adriana Kerchner da Silva ${ }^{1}$
}

Resumo: Este artigo apresenta o conceito de malungaje de Branche (2009), que afirma que há uma rede de reconhecimentos e afetos entre escritores e intelectuais negros na América, motivada por um sentimento de união a partir da experiência de serem parte da diáspora africana. Com base no conceito, analisam-se cinco poemas do escritor gaúcho Oliveira Silveira, "Alô", "Em Cuba", "Antilhas", "Haiti" e "Platinos", em que o autor explicitamente recupera nações e regiões da América Latina nas quais a participação negra é evidente, mesmo que muitas vezes negada. Nesses cinco poemas, Silveira estabelece essa rede de malungos de que fala Branche (2009) e insere-se também como parte dessa união outernational.

Palavras-chave: Malungaje; Oliveira Silveira; Literatura Afro-latino-americana.

Abstract: This article presents Branche's (2009) malungaje concept, which states that there is a network of recognitions and affections among black writers and intellectuals in America, motivated by a feeling of togetherness from the experience of being a part of the African diaspora. Based on the concept, five poems by the gaucho writer Oliveira Silveira, "Alô", "Em Cuba", "Antilhas", "Haiti" and "Platinos", are analyzed, poems in which the author explicitly mentions countries and regions in Latin America in which the black participation is evident, although often denied. In those five poems, Silveira establishes that network of malungos mentioned by Branche (2009) and inserts himself as part of that outernational union.

Keywords: Malungaje. Oliveira Silveira; Afro-Latin-American Literature.

\author{
Canta América \\ Não o canto de mentira e falsidade \\ que a ilusão ariana \\ cantou para o mundo \\ na conquista do ouro \\ nem o canto da supremacia dos derramadores de \\ sangue \\ das utópicas novas ordens \\ de napoleônicas conquistas \\ mas o canto da liberdade dos povos \\ e do direito do trabalhador...
}

(Solano Trindade, Cantares da América)

\footnotetext{
${ }^{1}$ Mestranda em Letras pela Universidade Federal do Rio Grande do Sul (UFRGS).
} 

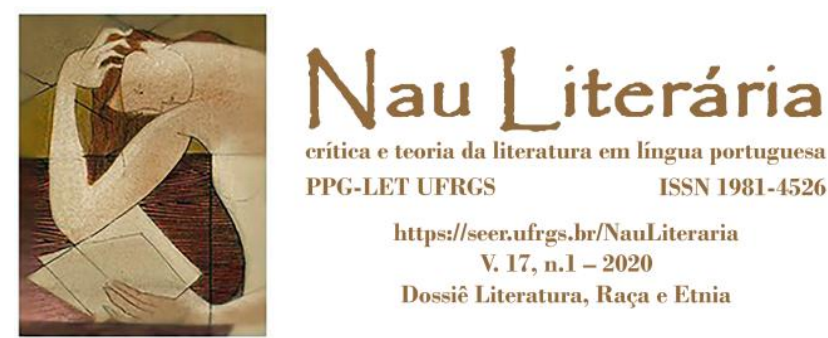

Desde o final do século XIX, com o surgimento do movimento do PanAfricanismo, diversos movimentos culturais e estéticos eclodiram com a finalidade de unir os negros do mundo todo, em uma "solidariedade sem fronteiras" (SANTOS, 2007, p.1), lutando contra os silenciamentos impostos sobre eles e pela redesignação de fazer literário que não mais estivesse subserviente aos modelos europeus, mas que recuperasse suas origens africanas e as expressasse dentro da literatura. Os movimentos do Renascimento do Harlem, do Indigenismo Haitiano, do Negrismo Cubano e da Negritude foram diretamente influenciados pelo pan-africanismo, cada um tendo suas características próprias e momentos de ascensão diferentes. Discutir-los-ei brevemente como um preâmbulo para o conceito de malungaje, formulado por Branche (2009) para pensar a poética da diáspora africana.

Como fundador, o Pan-Africanismo surgiu no final do século XIX nos Estados Unidos, com a doutrina principal de união dos negros de todo o mundo, especialmente estabelecendo contatos entre os negros estadunidenses e dos países africanos, por meio de conferências e congressos, ocorridos no início do século XX. Alguns dos seus principais nomes são W. E. B. Du Bois, cuja vertente "propugnava uma solidariedade negra para além da geografia ou da classe, adotando o reconhecimento da identidade negra na sua realização nacional, integrada e assimilada à nação, e solidária com os africanos e a restante diáspora fora da África" (SANTOS, 2007, p.4), e Marcus Garvey, conhecido por defender o retorno de todos os negros estadunidenses à África.

O primeiro movimento estético decorrente do Pan-Africanismo foi o Renascimento do Harlem, nos Estados Unidos, por volta dos anos de 1920. Escritores, como Langston Hughes, muito influente entre os escritores e intelectuais negros, e cantores, como Josephine Baker, produziram arte com "consciência grupal e racial, de herança africana e reivindicação sócio-política" (LARANJEIRA, 1995, p.26), que buscava a valorização das pessoas negras e de sua arte. Posteriormente, surgiram nas ilhas caribenhas dois movimentos estéticos também diretamente influenciados pelo PanAfricanismo, o Indigenismo Haitiano e o Negrismo Cubano. O primeiro defendia o "retorno à cultura autóctone e popular, valorizando os falares crioulos e o vodu" 


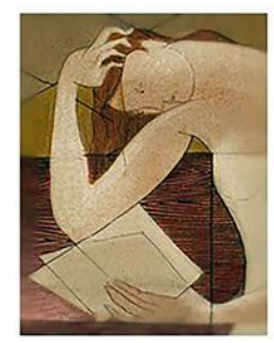

(SANTOS, 2007, p. 6), reavendo a herança africana na sociedade haitiana. O Negrismo cubano, por outro lado, foi iniciado por artistas brancos - posteriormente houve a presença de negros - em um momento em que a cultura branca começava a descobrir África e ver, com exotismo, a beleza que havia na arte do continente. Em Cuba, o principal nome do movimento é o escritor negro Nicolás Guillén, também muito influente e que travou diálogo direto com Langston Hughes. Guillén, segundo Gonçalves (2003, p.144), tinha como principal afã a "criação de uma poesia com uma inconfundível marca cubana que refletisse - e ajudasse a consolidar - a identidade nacional", conseguindo, por meio do uso da inclusão do ritmo do gênero musical son em sua poesia, alcançar o "verdadeiramente cubano", buscando um "espírito mestiço". Desse modo, fica evidente que, por mais que de fato trouxesse à tona a importância da cultura negra na formação cultural de Cuba, seu interesse estético atendia à ideologia nacional da "cubanidad" enquanto representada pela mestiçagem, não reivindicando uma negritude contestadora, como nos outros movimentos.

Por fim, cabe especial destaque ao movimento da Negritude, surgido em meados dos anos de 1930 em Paris, encabeçado pelo martinicano Aimé Cesáire, pelo senegalês Léopold Sédar Senghor e pelo guianense Leon Damas. O nome, em francês, recupera o termo nègre, utilizado para se referir despectivamente aos negros, ressignifica-o e reverte seu sentido, estabelecendo um movimento revolucionário na linguagem. Em português essa força no termo se perde, mas cabe destacar essa transformação inicial realizada pelos escritores. Segundo Santos (2007, p. 8),

A Negritude utilizou-se essencialmente da poesia como meio de propagação de suas idéias e como movimento poético, com valores estéticos diferenciados dos padrões ocidentais e inseridos no seu grito de revolta, encontrou ecos em todo o mundo negro, principalmente na África e nas Américas, transformando a poesia numa arma de combate contra a assimilação cultural, o racismo e o colonialismo europeu, a que os negros estavam submetidos, convertendo o movimento poético-cultural em políticosocial, que enorme influência teria na luta pela independência dos estados africanos colonizados pelas nações européias, e na conscientização do negro em diáspora que o levou a reivindicar o seu lugar na sociedade e na história do país onde vive e teve participação ativa em sua construção.

O movimento foi muito influente em todo o mundo, inclusive repercutindo nas lutas por independência nos países africanos, como destacado por Santos (2007), 

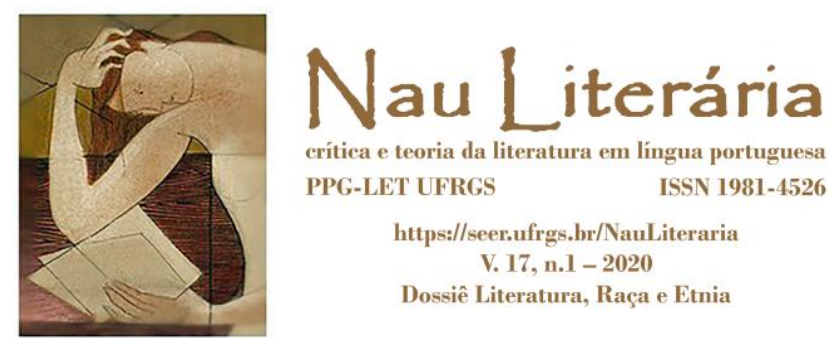

especialmente por meio de Sédar Senghor, que foi presidente do Senegal de 1960 a 1980. Também influenciado por todas essas importantes correntes do século XX, Branche (2009) elabora o conceito de malungaje buscando compreender a poética da diáspora africana, pensando particularmente no âmbito latino-americano. Nesse sentido, desloca o modelo "de identidade negra centrado nos EUA e no inglês sobre as complexas experiências das populações de descendência africana" (HAYES, 2000, p. 47 apud BRANCHE, 2009, p. 27²) para a América Latina, pensando na integração desta região. Esta virada me parece interessante porque desvela, também, assimetrias existentes nesses movimentos, fortemente centrados nos Estados Unidos e Europa, em detrimento de diversos países latino-americanos, inclusive do Brasil, com sua população majoritariamente negra.

Desse modo, neste trabalho, interessa-me discutir o ainda pouco difundido conceito de malungaje, aplicando-o para pensar os poemas "Alô", "Em Cuba", "Haiti", "Platinos" e "Antilhas", do escritor gaúcho Oliveira Silveira, parte da obra Roteiro dos tantãs (1981). A motivação deste estudo parte da observação de que a integração de Oliveira Silveira a uma literatura afro-latino-americana é algo ainda pouco estudado, enquanto sua afiliação aos movimentos da Negritude e do Pan-Africanismo é mais discutida. ${ }^{3}$ Como hipótese para esse apagamento de sua "faceta latino-americana", por assim dizer, aponto que o Brasil, de modo geral, segue sem identificar-se com os outros países da América Latina, o que se reflete também nas concepções de estudo dos pesquisadores. Nesse sentido, espero de alguma forma poder contribuir para o estudo desses poemas em específico, que trazem tão evidente mensagem de integração da América a partir da negritude, mas que acabam sendo pouco discutidos.

Não posso deixar de destacar, no entanto, que a obra do poeta ainda é, de modo geral, muito pouco estudada, mesmo no âmbito da literatura negra brasileira.

\footnotetext{
2 Todas as traduções de Branche (2009) são minhas.

${ }^{3}$ Para análises da obra de Oliveira Silveira a partir do viés da Negritude e/ou Pan-Africanismo, cf. Santos (2007), Dantas (2006) ou Silva (2013a e 2013b). Em todos estes textos, sua obra é analisada comparativamente com autores/teorias de países africanos ou menciona-se sua citação dos spirituals estadunidenses, pouco ou nada falando sobre sua relação com a América Latina.
} 

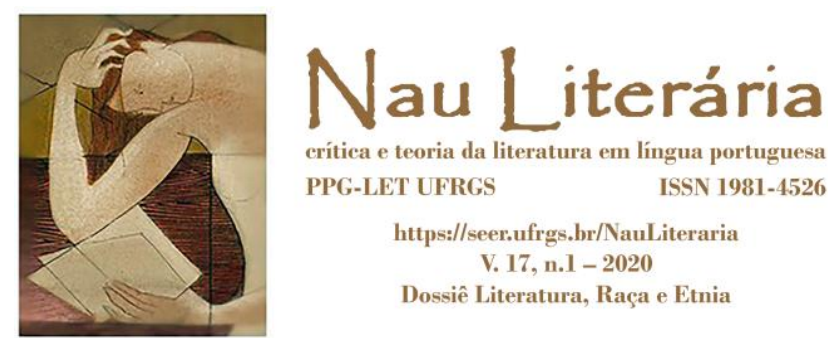

Provavelmente por pertencer a um estado que nega sistematicamente a existência de negros como parte da população, a obra de Oliveira Silveira é menos discutida que a de poetas do centro do país, mesmo ele tendo sido um dos fundadores da discussão da data do 20 de novembro como o Dia da Consciência Negra. Nesse sentido, mais uma vez o estudo de sua obra é importante para dar-lhe mais visibilidade no âmbito nacional.

Para atingir os objetivos propostos, este artigo trará, além desta introdução, (i) a discussão do conceito de malungaje, suas origens e objetivos; (ii) a análise dos cinco poemas de Oliveira Silveira, discutindo que aspectos de cada país/cultura é destacado pelo autor; e (iii) as considerações finais.

\section{Malungaje: uma poética da diáspora africana}

Nesta seção, discutirei o conceito de malungaje, elaborado pelo pesquisador guianense Jerome Branche, e seus objetivos, enquanto proposta poética para se pensar a diáspora africana na América. Inicialmente, o pesquisador aponta que a diáspora, embora atualmente bastante discutida, segue um desafio teórico, levando-o a buscar "sua aplicabilidade ao ativismo discursivo do que é negro no contexto mais amplo do regime racial pós-colonial e globalizado" (BRANCHE, 2009, p. 25). Recuperando os autores Patterson e Kelly (2000), Branche define a diáspora "tanto como processo, por sua continuidade translocal e transgeracional, como condição, por sua localização dentro de hierarquias globalizadas de raça e gênero" (BRANCHE, 2009, p. 26).

Ademais, destaca a relevância para os negros contemporâneos de ter um olhar para o passado, que "se daria para o velho continente como referente epistêmico primário ou, alternativamente, para qualquer das muitas localidades pós-africanas e pósemancipação onde residiram" (p. 25), e também para o futuro, em uma "projeção utópica para um futuro de recuperação e completude" (p. 26). Nesse sentido, é por meio de um "saudável envolvimento com o passado, como parte de uma formidável tarefa teórica da diáspora como recuperação, que uma discursividade poética e analítica com ‘potencial orientador da ação’ (Henry, 2000: 104) poderia ser produzida” (p. 26). 

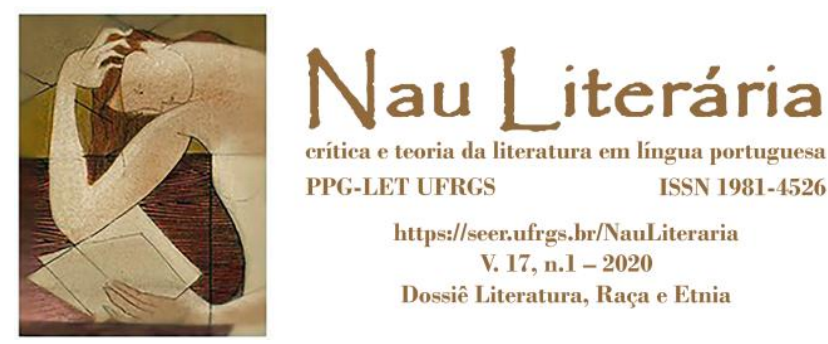

Essa recuperação do passado africano, como mencionado na introdução, foi mote de todos os movimentos citados, desde o Pan-africanismo até a Negritude. Estabeleceu-se, assim, o que Santos (2007, p.1) define como uma "solidariedade sem fronteiras para com as pessoas da raça negra, não importando o local de nascimento e sim a cor da pele e a origem comum". Como exemplo disso, Branche (2009) cita os encontros entre Nicolas Guillén e Langston Hughes, que influenciaram tantas pessoas, desde poetas de seus países, até brasileiros como Solano Trindade e o próprio Oliveira Silveira. O teórico percebe, desse modo, que "uma sensibilidade translocal e diaspórica constitui uma importante faceta dos poetas e escritores de prosa afrolatinos desde pelo menos o período pós-negrista, de 1940 adiante, em lugares tão diversos quanto Colômbia, Uruguai, Cuba, Equador, Panamá e Brasil” (BRANCHE, 2009, p. 28).

Como já mencionado na introdução deste trabalho, seu intento passa por desviarse de um modelo da diáspora centrado inteiramente nos Estados Unidos, como foi o movimento do Pan-Africanismo, por exemplo, buscando uma dimensão afro-hispana ou afrolatino-americana do campo dos estudos sobre a diáspora. Procura, além disso, responder uma pergunta lançada por Herman Bennet, sobre "quando, onde, por que e sob que condições a escravidão e a opressão racial produziram uma 'consciência negra'?" (BRANCHE, 2009, p. 29).

Para responder a essa questão, utiliza o conceito de malungaje, recuperando o laço que unia muitas pessoas escravizadas que compartilharam a experiência da travessia do Atlântico nos navios negreiros. O conceito advém da palavra "malungo", relativamente comum no português brasileiro, inclusive dicionarizada. ${ }^{4}$ Branche (2009, p. 29) menciona que a palavra vem dos idiomas quicongo, umbundu e quimbundu, falados pelos povos bantus da África central e oriental, e que reúne ao menos três ideias em si, dependendo das coordenadas de lugar e tempo: "i) de parentesco ou irmandade em seu sentido mais amplo, ii) de uma canoa grande e iii) de infortúnio". Logo, segundo a definição de Slenes (1995 apud BRANCHE, 2009, p. 29), no Brasil colonial "meu

\footnotetext{
4 O Dicionário Aulete online, por exemplo, tem uma entrada para o termo. Disponível em: <http://aulete.com.br/malungo>, acesso em: 10 abr. 2020.
} 

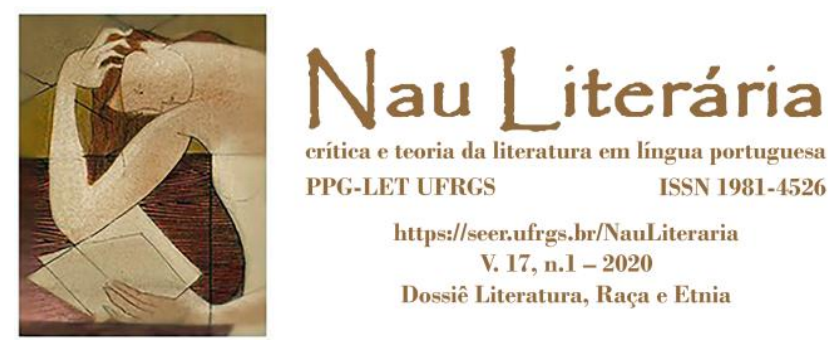

malungo se referia a 'meu camarada-com-quem-compartilhei-o-infortúnio-da-canoagrande-que-cruzou-o-oceano"”. Essa mesma definição está registrada pela Enciclopédia Brasileira da Diáspora Africana, organizada por Nei Lopes (2011 s. v. Malungo), demonstrando, de fato, a usualidade do termo dentro do português brasileiro. Outro ponto interessante destacado por Branche (2009, p. 32-33) é que termos semelhantes eram usados em outros países latino-americanos, como "malongue" em Trinidad, "batiment" no Haiti, "shipmate" na Jamaica, "sipi" ou "sibi" no Suriname e "carabela" em Cuba, todos referindo-se aos companheiros da travessia forçada pelo Atlântico.

Em mais um movimento de ressignificação - anteriormente realizado pelos teóricos da Negritude, ao deslocarem o sentido pejorativo do termo nègre -, Branche utiliza a experiência absolutamente traumática do tráfico negreiro sofrida pelos negros da diáspora como algo que gerou uma comunidade (forçada) entre eles, expressada com força nos palenques hispano-americanos e nos quilombos brasileiros. Criou-se, desse modo, um parentesco ficcional entre os negros, com um espírito de "família estendida", que afirmou "ideias de intersubjetividade, reconhecimento mútuo e solidariedade subalterna" (BRANCHE, 2009, p. 32).

A malungaje seria, nesse sentido, "uma espécie de tropo fundacional (contradiscursivo) para a política de identidade e o ativismo cultural e político negros, e como ponto de partida para considerações sobre a diáspora" (BRANCHE, 2009, p. 34). O conceito é, "como reconhecimento e como resistência, transnacional em alcance ou, melhor dizendo, outernational ("externo-nacional”) como a apropriação morfossintática Rasta de Paul Gilroy poderia sugerir" (p.34). Ademais,

\footnotetext{
O conceito de outernational ganha sua relevância e força porque transgride e transcende as constrições homogeneizadas do Estado nacional, geopoliticamente limitado como é, e possibilita uma espécie de conceito horizontalista diaspórico vernáculo, que é fortalecido, por sua vez, pela valência numérica da população sempre móvel, com suas memórias e alianças a seus outros lugares de origem. (BRANCHE, 2009, p. 34)
}

Tendo em vista o conceito de malungaje como essa rede de reconhecimento mútuo estabelecida entre as pessoas negras da diáspora a partir da ressignificação da experiência traumática do navio negreiro, quero pensar os poemas de Oliveira Silveira que serão analisados na continuação, visto que estabelecem essas interligações com 

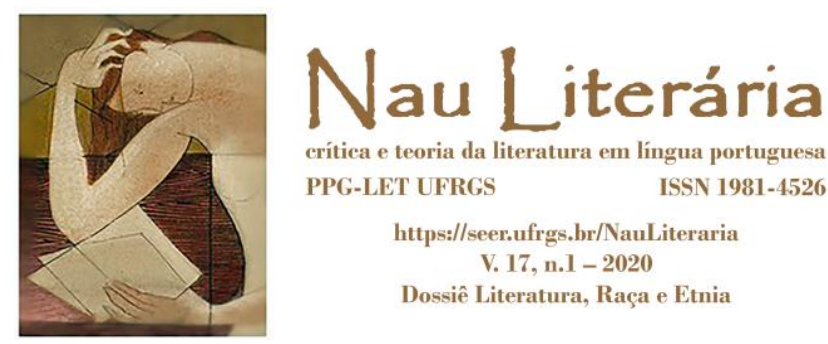

outros países da América Latina, inserindo a poesia do escritor gaúcho dentro dessa rede de reconhecimentos dos escritores negros da América.

No artigo de Silva (2019), a autora utiliza, também, o conceito de malungaje, em paralelo com o de quilombismo de Abdias do Nascimento (1980), afirmando que existe, sim, uma rede de reconhecimentos "e afetos por parte de autores e intelectuais negros que percebem uma América Latina de forma mais integrada" (SILVA, 2019, p. 119). Para exemplificar essa ideia, recupera poemas de Langston Hughes (“I too”, de 1932), Nicolás Guillén (“Coplas Americanas”, de 1960, em que cita uma possível união da América Latina), da uruguaia Virginia Brindis de Salas (“Es verdad, sí señor”, de 1947) e do brasileiro Solano Trindade ("Nicolás Guillén" e "Eu também sou amigo da América"). Percebendo a ausência de Oliveira Silveira nesta discussão, este artigo novamente se justifica como complementar à análise de Silva (2019).

\section{Oliveira Silveira, escritor negro latino-americano}

Nesta seção, analisarei cinco poemas que compõem o livro Roteiro dos tantãs (1981), do escritor gaúcho Oliveira Silveira, “Alô”, "Em Cuba”, "Haiti”, "Platinos" e "Antilhas", observando quais relações o autor traça em cada poema e de que maneira ele forma e se integra em uma rede de relações e reconhecimentos entre os negros da América Latina. Esta ideia é apoiada por Bernd (1987, p. 125), quando a autora afirma, sem sombra de dúvidas, que "Oliveira Silveira está perfeitamente integrado à corrente negritudinista existente nos grandes centros de irradiação cultural do país e também do Caribe, pois muitas vezes aparecem em epígrafe poemas de Guillén e Césaire”. Nesse sentido, o que farei aqui será apontar alguns poemas em que essas relações aparecem de forma bastante explícita.

A autora faz uma breve síntese sobre a obra Roteiro dos tantãs (1981), interessante de ser ressaltada, já que a análise aqui feita é de poemas esparsos, que sozinhos não dão conta do livro como um todo. Afirma Bernd (1987, p. 128) que

No último livro, Roteiro dos tantãs, a consciência trágica emerge no discurso poético que se torna, cada vez mais, o lugar privilegiado da purgação e do enfrentamento do poeta consigo mesmo. A preocupação com as origens, a ligação com a África, o elogio 


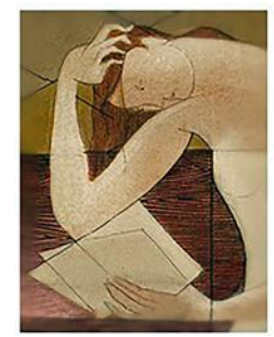

e a solidariedade com os irmãos do Caribe, mas, sobretudo, a acusação contra a forma preconceituosa com que o branco estabelece as regras de relação com o negro são a matéria-prima dos poemas.

Outro ponto destacado por Zilá Bernd, agora sobre a obra de Oliveira Silveira de modo amplo, é que parte do seu "molde textual" é de procurar suas origens e demonstrar um desejo de união com todos os negros da América, em uma "recusa do poeta de testemunhar sua própria destruição enquanto sujeito" (BERND, 1987, p. 128). Logo, percebe-se que esse sentimento de união aos outros escritores e intelectuais negros é comum a toda sua obra poética. Feitos os breves comentários sobre sua obra de forma ampla, partamos à análise dos poemas selecionados, a começar por "Alô" que, embora não seja o primeiro poema na ordem do livro, foi escolhido para abrir a discussão, pois traça uma rede de relação com a toda a América.

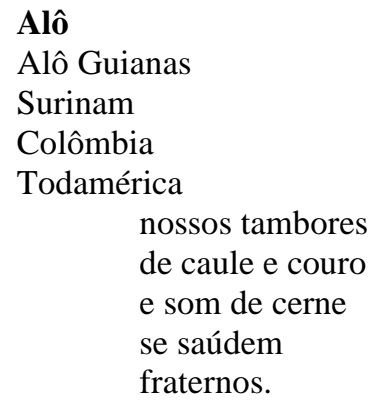

(SILVEIRA, 2012, p.151)

Neste poema, o escritor menciona pontualmente três regiões cuja população negra é bastante expressiva, embora não sejam lembradas com frequência. Em outros poemas, que serão analisados na sequência, menciona Cuba e Haiti, por exemplo, nações frequentemente citadas quando falamos de cultura negra. Aqui, por outro lado, recupera as Guianas e o Suriname, três pequenas ilhas no Caribe cuja presença negra é expressiva pelo passado colonial marcado pelas plantações de cana de açúcar, e a Colômbia, país muitas vezes lembrado pela população indígena (especialmente atrelada à Cordilheira dos Andes), mas cuja população negra soma 9,34\% do total do país (COLÔMBIA, 2018). 

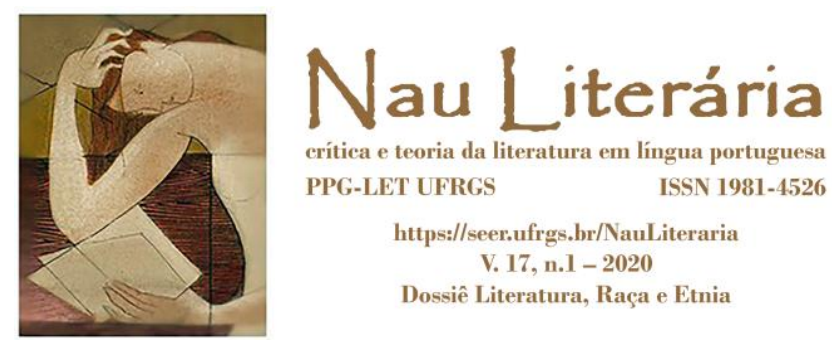

No final da estrofe, cita "Todamérica", apontando para uma possível presença negra em toda a América Latina, algo confirmado pela história do continente. Em todos os países houve colonização e consequente escravização de pessoas negras, o que garantiu que, por menor que seja, haja presença de negros em todos os países. Segundo relatório do Banco Mundial (2018), o país com mais negros na América Latina, numericamente falando, é Brasil, seguido de Venezuela (outra nação lembrada pela presença indígena), Colômbia, México, Equador (também considerados países indígenas/mestiços, sem levar em conta a população negra) e Cuba, com os outros países tendo menos de 1 milhão de habitantes negros. O relatório não inclui os países do Caribe anglófono e francófono, o que explica a ausência do Haiti e Jamaica, por exemplo. Mesmo em países que não incluem a variante "negro" nos censos, como Chile, especula-se que haja população negra, mesmo que muito pequena.

No poema, o escritor recupera os tambores como símbolo de união dos negros de Todamérica, tema bastante explorado dentro da literatura negra latino-americana de modo geral. Mitologicamente, afirma-se que foi por meio do toque dos tambores que os escravizados convocaram uns aos outros para alçarem-se na Revolução Haitiana, ocorrida em $1804 .{ }^{5}$ O tambor tantã, mencionado por Oliveira Silveira no título do livro e também no poema "Em Cuba", discutido a seguir, é, segundo Bernd (1987, p. 129), assim como outros instrumentos musicais, um dos "principais símbolos usados na convocação do povo negro à reunião, aliados à utilização da simbólica gauchesca que mediatiza a caminhada em busca das raízes primeiras". Essa afirmação é corroborada por Adolfo (apud Santos, 2007, p. 16), que aponta que Oliveira Silveira "apresenta o som do tambor (tantã) como símbolo de união entre os negros de toda a América (e de todo mundo), e também é o elemento de ligação com a ancestralidade africana".

Outro ponto que expressa tanto a integração dos negros da América de modo geral, como a inclusão de Oliveira Silveira nesse todo, é o uso de "nossos tambores".

\footnotetext{
${ }^{5}$ Digo "mitologicamente" porque não encontrei fontes históricas "científicas" que corroborem essa afirmação. No artigo de Tonet (2017), a pesquisadora menciona o uso de tambores na Revolução, mas sempre em relação à obra literária La isla bajo el mar. Sendo o artigo um estudo histórico-literário, podemos confiar na veracidade desta informação, mas com cautela.
} 

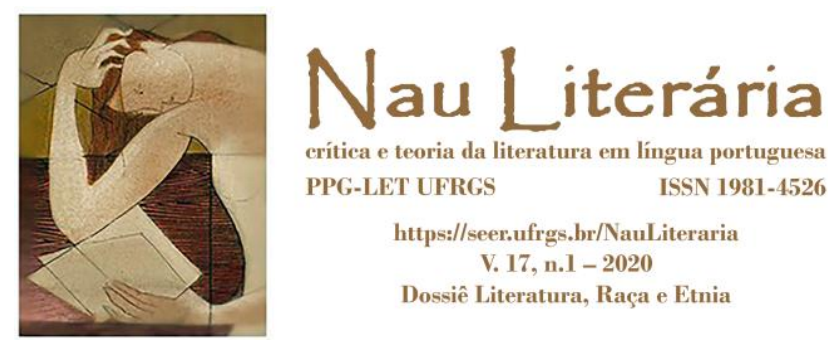

Assim como afirma Dantas (2006, p. 77), que, "mesmo sendo fruto de uma criação individual, os poemas [...] de Oliveira Silveira expressam sempre um anseio coletivo, que veiculado por um EU está sempre a falar de um NÓS, a reivindicar a integração de todos", aqui essa relação é ainda mais explícita pelo próprio uso do pronome possessivo no plural. Esse movimento ocorre também "Haiti" e "Platinos", discutidos mais adiante. Neste ponto específico, passemos à análise de "Em Cuba", que cita também o tantã como elemento de interligação.

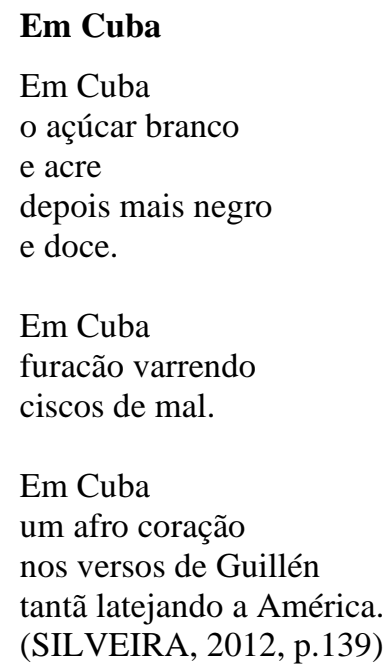

Neste poema, Silveira traz a importante menção ao açúcar, cujas plantações com alta necessidade produtiva foram usadas como justificativa para a escravização dos africanos. Cuba e Brasil, além de terem o açúcar como principal produto de exportação durante a colonização, foram os dois últimos países a abolirem a escravidão (Cuba em 1886 e Brasil em 1888). Na ilha, embora a população negra não seja tão numerosa quanto a do Brasil (aqui representa 56,10\%, segundo dados recuperados por Afonso (2019) do último censo do IBGE, e, em Cuba, 9,3\% - lá, o censo divide quem é "negro" de quem é "mulato ou mestiço", estes representando $26,6 \%$ da população -, segundo informações oficiais recuperadas por Alfonso (2016), há grande valorização do Estado, por meio de seus órgãos voltados à cultura, das contribuições dos negros para a cultura cubana. Como mencionado na introdução, quando discuti o movimento do Negrismo cubano, há muitos pesquisadores brancos, como Fernando Ortiz e Lydia Cabrera, com 


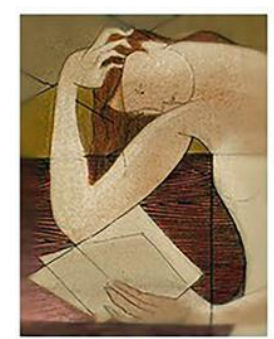

importantes e reconhecidos trabalhos que apresentam a participação dos negros na cultura nacional. Isso não significa, por outro lado, que não haja racismo em Cuba ou que a Revolução de 1959 tenha resolvido todos os problemas raciais do país. ${ }^{6}$

No poema, novamente Nicolás Guillén e seu "afro coração" são mencionados, demonstrando a real influência que o autor teve em outros escritores e intelectuais negros do período, sendo considerado como um dos mais importantes representantes de uma poética negra do seu país e da América como um todo. Como também discuti para o poema "Alô", neste poema o tantã é citado como algo que lateja a América, isto é, que faz pulsar o continente. Mais uma vez, temos um elemento que corrobora a tese que a negritude e seus símbolos podem ser um ponto interessante para pensar uma rede de relações na América, especialmente considerando o tambor como um instrumento musical envolvente, que histórica e mitologicamente convocou os negros à reunião, conforme já mencionei anteriormente.

Vizinhas de Cuba estão as Antilhas, tema do próximo poema a ser analisado:

Antilhas
No mapa
das Antilhas
mares
que se entulham
de ilhas.
Nas ilhas
das Antilhas
gente negra
que pontilha.
E quem chega
à escotilha
vê bater a miséria
nas quilhas.

(SILVEIRA, 2012, p. 140)

\footnotetext{
${ }^{6}$ A tese de Oliveira (2015) é importante fonte para essa discussão, pois inclui relatos de ativistas do movimento negro em Cuba e de outros habitantes do país sobre a "ambígua condição negra" no país, nos termos da pesquisadora. Embora o país estruturalmente não seja racista, na medida em que existem políticos negros, por exemplo, o que não ocorre no Brasil, e que os indicadores sociais dos negros sejam similares aos do resto da população, não há políticas estatais específicas para essa população, em nome da ideologia de uma cubanidade mestiça e da ideia de que os problemas sociais do país são advindos de questões de classe, não raciais ou de gênero, por exemplo, já que o Estado é, em tese, de orientação marxista.
} 


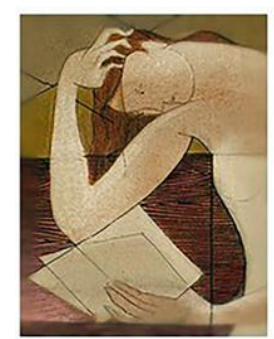

Novamente em um movimento de alargamento do foco, Oliveira Silveira menciona as Antilhas de forma geral, apontando toda a região como espaço notadamente negro, especialmente pela força que tiveram as plantações de açúcar em diversos países. Mesmo tendo colonizações por países diversos, como Jamaica pelos britânicos, Haiti pelos franceses e Cuba pelos espanhóis, por exemplo, a escravização foi ponto comum, garantindo uma população negra expressiva. Outro ponto comum, denunciado no poema, é a miséria em que vive grande parte dessa população, posto que o Haiti, por exemplo, é considerado o país mais pobre da América. Ademais, é importante ressaltar que muitas dessas ilhas hoje não constituem países independentes ou totalmente independentes, uma vez que Porto Rico é um Estado livre associado aos Estados Unidos, assim como Martinica e Guadalupe são departamentos ultramarinos da França. A Jamaica é parte da Comunidade Britânica, embora seja um Estado soberano, apenas para citar alguns exemplos. Desse modo, nota-se que a situação econômica e política de muitos desses países não é a melhor possível, o que adiciona mais um caráter de denúncia social no poema. Falando mais especificamente de um dos países das Antilhas, temos o poema "Haiti":

Haiti

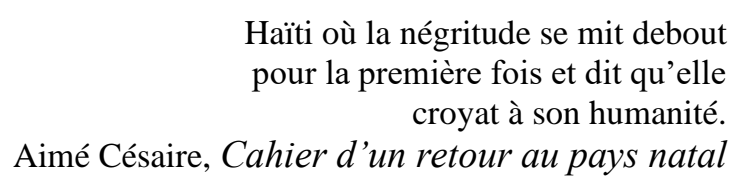

Grande teu passado

célebre na história

e que alto teu grito liberto

até hoje movendo nossos braços

num gesto altivo de lança em riste!

Haiti,

sagrado no culto vodu, heroico em Dessalines, soberbo em Toussaint-Louverture,

"o primeiro dos negros", Haiti!

Haiti, 


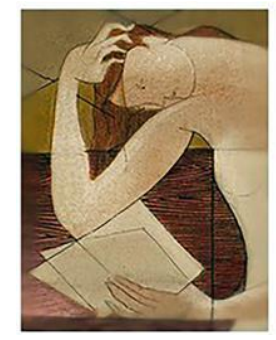

meu verso quisera ser

ponta de lança e guizo de serpente

para expressar-te a ti!

(SILVEIRA, 2012, p. 141)

A Revolução Haitiana, já mencionada, terminou em 1804, tendo conseguido a independência da França e a abolição da escravidão de forma concomitante, e tendo sido um movimento bem-sucedido liderado por negros escravizados. Ferrer (2012) aponta que a Revolução, ao mesmo tempo em que é uma ausência na história - posto que não é citada por muitos pesquisadores sobre as Revoluções mundiais ou, quando é mencionada, é apenas de passagem, não tendo o mesmo enfoque que a própria Revolução Francesa -, foi amplamente divulgada na época dentro dos outros países escravistas, que temiam que ocorresse um outro Haiti ou que seus escravizados soubessem da Revolução e, a partir dela, percebessem seu potencial de revolta. Por seu caráter de revolução negra, é um fato histórico muito citado pelos escritores e intelectuais negros como um dos principais pontos altos de sua história na diáspora.

A força da Revolução é expressa por Oliveira Silveira quando menciona o passado grande e célebre do Haiti e que o "alto grito liberto" até hoje move os braços dos negros, demonstrando que atualmente a força desse movimento de insurreição segue potente. Aqui também Silveira usa "nossos braços", incluindo-se enquanto corpo negro nesse grande grupo de pessoas afetadas pela Revolução Haitiana. Na estrofe seguinte, usa três adjetivos para descrever a ilha, "sagrado", "heroico" e "soberbo", e três pontos importantes para a negritude no país, a religião vodu e dois dos heróis da Revolução. O vodu é a religião de matriz africana tradicional do Haiti, baseada no culto aos loas (também chamados de voduns) dos povos euê, fom e maí, misturada com o catolicismo, religiões dos povos indígenas originários da ilha e de outros povos africanos, como os congos, iorubás e igbos. Fortemente combatida pelos missionários católicos durante a colonização, era um ponto de união entre os escravizados, sendo apontada como responsável pelos movimentos de independência/abolição. Santos (2010) sublinha que, durante uma cerimônia do vodu, os negros presentes "firmam um pacto de sangue onde todos se comprometem com a luta pela libertação do país, exterminação dos brancos e a 

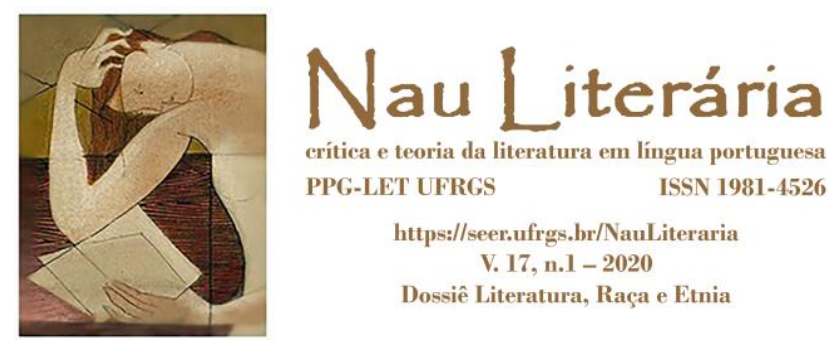

criação de uma sociedade autônoma". Após a independência, a religião seguiu como símbolo da insurreição negra, sendo levada pelos governos como símbolo nacional. Durante o período das ditaduras dos Duvalier, Papa Doc e Baby Doc, o vodu seguiu, uma vez que ambos eram praticantes da religião, informação corroborada pela reportagem de Cabral (2018).

As figuras históricas citadas, Dessalines e Toussaint L'Ouverture, são dois dos heróis da Revolução Haitiana, ambos tendo sido escravizados em parte de suas vidas. L'Ouverture foi o maior líder da Revolução, e Dessalines, posteriormente à prisão de L'Ouverture e sua extradição à França, proclamou a independência e foi o primeiro governante do país, autoproclamando-se o Imperador Jacques I. Importante mencionar brevemente que, segundo Rosa e Pongnon (2013), ambos tinham ideais diferentes para a nação haitiana. L'Ouverture buscou uma certa conciliação com a França, não tendo oficializado a independência na primeira constituição haitiana de 1801. Nela, assinada por L'Ouverture, “o colonialismo não é questionado e L'Ouverture assumia explicitamente que o domínio colonial do Império francês exercia pleno domínio sobre o território haitiano, sendo ele constitucionalmente designado Comandante em chefe e governador-geral da ilha" (ROSA; PONGNON, 2013, p.464), cargo exercido de 1795 a 1802. Nesse mesmo ano, foi preso e enviado à França por traição à Coroa, deixando a revolução inacabada. Quem definiu os rumos do país foi Dessalines, responsável pela proclamação da república, e por ser o primeiro governador do país, como mencionado. Ambos são figuras históricas relevantes e constantemente retomadas quando se trata de importantes líderes revolucionários negros, mesmo com suas contradições.

$\mathrm{Na}$ estrofe final, afirma o poeta que seu verso quisera ser "ponta de lança e guizo de serpente" para expressar a grandeza do Haiti, novamente demonstrando a relevância que o país, "o primeiro dos negros", toma dentro do que poderíamos chamar de história negra da América. Ademais, é relevante destacar a epígrafe do poema, reproduzida aqui porque cita Césaire e seu célebre livro Cahier d'un retour au pays natal (1939). Conforme Bernd (1987), em citação já registrada neste artigo, as epígrafes que Oliveira Silveira faz de escritores como Guillén e Césaire são fortes indicativos de sua filiação às 


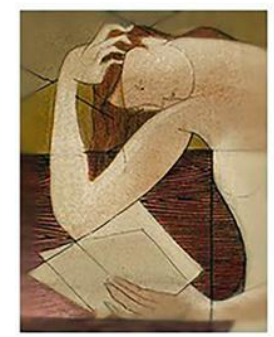

correntes da negritude. Ademais, a autora aponta que essa citação de outros escritores por epígrafes é indicativa da vocação da poesia negra para a polifonia. Afirma ela que

na medida em que os nossos poetas propõem-se a escrever (graphein) sobre (epi) poetas, como [...] o norte-americano Langston Hughes e os antilhanos Aimé Césaire e Nicolás Guillén, isto traduz uma intencionalidade de assumir os seus lemas e as suas bandeiras e de integrar uma corrente literária ainda mais abrangente do que a nacional, que é a corrente internacional da negritude. (BERND, 1987, p. 83)

Desse modo, a epígrafe e a menção a Guillén no poema "Em Cuba" demonstram a filiação de Oliveira Silveira à poesia negra latino-americana interessada em discutir a negritude de forma crítica, observando e denunciando os modos que os negros são tratados pelas sociedades brancas e buscando saídas para essas situações.

Por fim, analisarei o poema "Platinos", em que aparecem duas temáticas relevantes na poesia de Oliveira Silveira: sua afiliação à América Latina como um todo e a ausência dos negros na história oficial do Rio Grande do Sul, Argentina e Uruguai, em seus poemas afro-gaúchos.

\section{Platinos}

I

(Argentina)

Milonga

tango

malambo

eu chego

negro

ao Prata

sinto frio branco.

Milonga

tango

malambo

familiares

essas palavras

quentes

me agasalham.

II

(Llamada)

Perto do Uruguai

e longe de onde

é Montevidéu.

Mas rompe o candombe, 


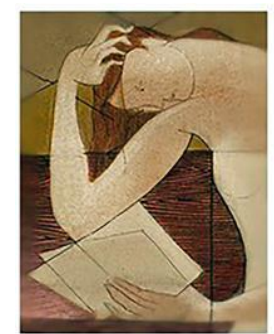

mãos escuras lá

tocam os tambores.

De repente aqui

nenhum som - e sim!

coração responde.

(SILVEIRA, 2012, p.150)

Na Argentina e no Uruguai, do mesmo modo que no Rio Grande do Sul, existe uma forte ausência no discurso oficial da história da participação dos negros na formação dos Estados. No nosso caso local, segundo Santa (2014, p. 285), "permanece no imaginário comum a ausência da presença dos negros na formação do Rio Grande do Sul”, ocasionada, na visão de Gutfreind (1990 apud Santa, 2014, p. 285), por uma orientação da historiografia oficial gaúcha, que buscou inventar uma história local vinculada a Portugal, excluindo o negro. "É daí que advém o zelo pela história açoriana, o aprofundamento da busca documental destes laços de origem, o retorno ao passado lusitano, ignorando as íntimas relações com a África negra”.

Processos muito similares ocorreram nos dois outros países, que também se afirmam como fortemente influenciados pelos colonizadores europeus e com população esmagadoramente branca. No Uruguai, conforme recupera Andrews (2011), no livro que comemorava o centenário da independência, de 1932, eles se orgulhavam de serem a única nação da América a não ter "um núcleo que lembre de sua população aborígene" e de que a população descendente de negros escravizados tivesse diminuído até tornarse uma porcentagem "insignificante na totalidade da população" (ANDREWS, 2011, p. 17, tradução minha). Ademais, para "afastar qualquer dúvida sobre o assunto, o capítulo sobre demografia começava com esta frase: 'povoa o Uruguai a raça branca, em sua totalidade de origem europeia" (p.17). Acrescenta que os livros didáticos das escolas uruguaias insistiam também nessa questão, afirmando o Uruguai como um país excepcionalmente democrático e a importância da imigração europeia na formação da sociedade, dois fatores associados intimamente pela ideologia dominante (ANDREWS, 2011, p. 18). Contrariamente a essas afirmações, os censos atuais demonstram que os negros constituem entre 6 a 9\% da população nacional do Uruguai (ANDREWS, 2011, p. 24). 

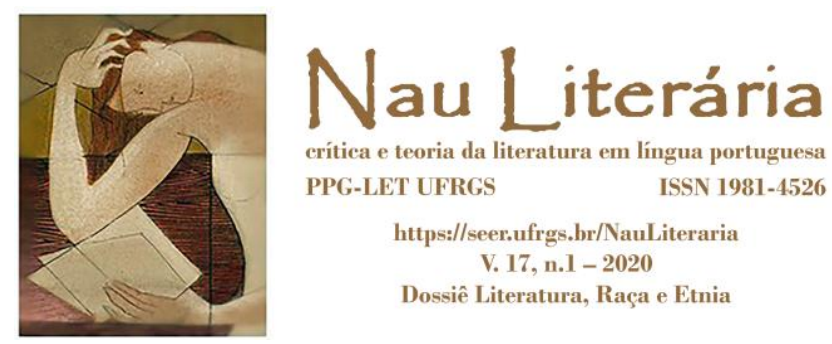

$\mathrm{Na}$ Argentina, por sua vez, existe movimento similar de afirmação de uma “argentinidade sem negros, expressão de uma construção ideológica que fez do estereótipo de 'nação de raça branca e de cultura europeia' um elemento-chave da identidade argentina" (YAO, 2002, p. 2, tradução minha). Para essa construção, segundo a mesma autora, ocorreu uma intencional ocultação da participação dos negros no país, especialmente no nível educacional, muito influenciados por intelectuais racistas como Faustino Sarmiento, autor de Facundo: civilização ou barbárie (1845) e importante ideólogo da educação argentina. Afirma Yao (2002, p. 3) que ele

\begin{abstract}
Acreditava que as ideias e o esclarecimento não se aprendiam, mas se herdavam geneticamente. Assim, [...] se requeria uma real infusão de genes brancos, representantes da civilização. [...] Barbárie era o resto e para conseguir o progresso, a Argentina deveria apagar ou destruir o que havia de bárbaro em seu seio. Tratava-se de ser ou não selvagem, e para não ser selvagem era necessário civilizar.
\end{abstract}

Trago essa citação porque situações semelhantes ocorreram no Brasil, que também teve sua dose de intelectuais racistas, como Gilberto Freyre, Nina Rodrigues e Monteiro Lobato. Voltando ao poema pontualmente, vemos a representação da Argentina como um país pretensamente embranquecido na primeira estrofe, quando há "eu chego/ negro/ ao Prata/ sinto frio branco". Posteriormente, por meio das palavras "milonga", "tango" e "malambo", sente-se agasalhado por termos tão familiares. Os três termos, além disso, referem-se a símbolos marcantes e reconhecidos da cultura gaúcha, cuja participação negra é frequentemente apagada, novamente para corresponder a um ideal de "gauchidade" branca e europeia. Como destacado por Martins (2017), a milonga e o tango têm origens negras, comumente apagadas do imaginário comum. $\mathrm{O}$ mesmo ocorre com o candombe uruguaio, mencionado na segunda parte do poema.

Tomado como parte fundamental da cultura uruguaia, o ritmo musical tem origens negras, constantemente apagadas em nome dessa unidade nacional branca. Aparentemente, nesta parte do poema o eu-lírico está longe de Montevidéu, cidade referência do Uruguai, sentindo-se também perdido. No entanto, quando rompe o som dos tambores do candombe, relocaliza-se e seu coração reconhece o som, permitindo que ele sinta novamente que está em um lugar familiar e confortável. 

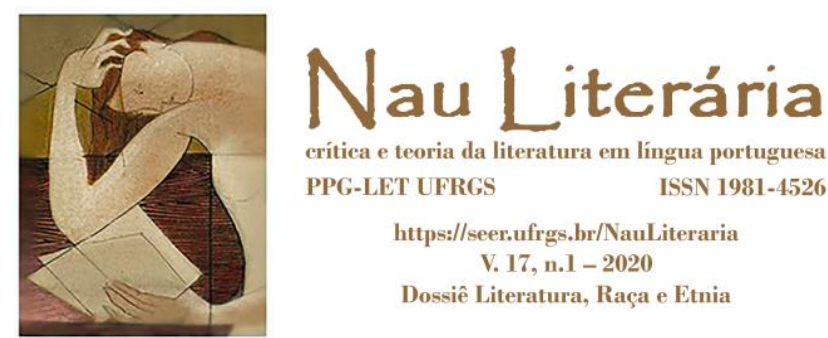

\section{Considerações Finais}

Nos cinco poemas analisados neste artigo, fica evidente a filiação de Oliveira Silveira a uma corrente latino-americana que pensa a negritude como fio condutor de uma possível união entre todos os povos. Ademais, busca o reconhecimento da participação ativa de negros na constituição da cultura dos países e de suas sociedades como um todo, enfrentando a ideia corrente de que apenas os brancos/europeus contribuíram para tais nações. Nesse sentido, ademais de reconhecer a participação negra, ao questionar a ideia de que apenas os europeus foram relevantes na formação dos Estados nacionais, indagamos também que outras participações foram apagadas, como as dos indígenas, chineses, judeus e tantos outros que aqui se instalaram ao longo da história do continente, e o quanto não se fala sobre esse assunto.

Uma possível integração da América Latina é tema caro desde os tempos de Simón Bolívar e de sua "Pátria Grande", atualmente sendo ressignificado por meio de outros vieses, considerando, como explicitado neste artigo, que a contribuição dos negros para a constituição deste continente deve ser reconhecida e celebrada. O conceito de malungaje, de Branche (2009), é um esforço nesse sentido, na medida em que ressignifica o trauma da travessia forçada do navio negreiro e retira dessa experiência o sentimento de solidariedade e união criado pelos negros em diáspora, formando uma rede de reconhecimentos e afetos. Essa rede é evidenciada com força dentro da literatura, na medida em que muitos escritores, como os já citados Solano Trindade, Langston Hughes, Nicolás Guillén, Virginia Brindis de Salas e Oliveira Silveira, se citam mutuamente dentro de seus poemas, estabelecendo um diálogo outernational, isto é, que rompe as fronteiras dos Estados-nação e forma uma rede mais ampla. Evidentemente, esta rede, assim como nos movimentos anteriores da Negritude e do Pan-Africanismo, se reporta à África como local de origem, valorizando a religião, símbolos, comida, danças, ritmos musicais, enfim, a cultura dos povos originários do continente africano e suas contribuições também para a formação da América enquanto continente. 

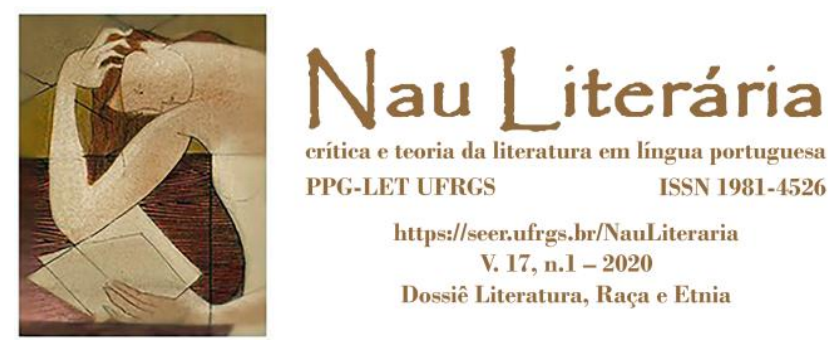

Oliveira Silveira, diretamente do sul do Brasil, integra-se também nessa rede de afetos, seja dialogando com os outros autores, seja trazendo para sua poesia menções sobre os outros países, suas grandes figuras heroicas, sua cultura, sua história e seu legado para o povo negro de modo geral. Ademais, cita nações que com frequência são esquecidas quando se discute negritude na América Latina, como Colômbia, Suriname e os países platinos, estes com uma forte construção histórica de serem nações brancas e europeias, fato compartilhado com o estado de origem de Oliveira Silveira, o Rio Grande do Sul. Nesse sentido, expande a rede formada apenas entre Brasil (esquecendose o RS), Haiti e Cuba, destacando a presença negra também em outras regiões, a despeito das ideologias correntes de que os negros até passaram pela América, mas rapidamente sumiram após os processos de abolição.

\section{Referências}

AFONSO, Nathália. Dia da Consciência Negra: números expõem desigualdade racial no Brasil. Agência Lupa, 2019. Disponível em:

<https://piaui.folha.uol.com.br/lupa/2019/11/20/consciencia-negra-numeros-brasil/>. Acesso em: 10 mar. 2020.

ALFONSO, Pablo. ¿Cuántos blancos hay en Cuba? Radio Televisión Martí, 2016. Disponível em: <https://www.radiotelevisionmarti.com/a/cuantos-blancos-hay-encuba/116939.html>. Acesso em: 10 mar. 2020.

ANDREWS, George Reid. Negritud en la nación blanca. Montevideo: Librería Linardi y Risso, 2011.

BANCO MUNDIAL. Afrodescendentes na América Latina: rumo a um marco de inclusão. Washington, DC: World Bank, 2018. Disponível em: < https://openknowledge.worldbank.org/bitstream/handle/10986/30201/129298PT.pdf?se quence $=12$ \&isAllowed=y $>$. Acesso em: 12 mar. 2020.

BERND, Zilá. Negritude e literatura na América Latina. Porto Alegre: Mercado Aberto, 1987.

BRANCHE, Jerome. Malungaje: Hacia una poética de la diáspora africana. Revista Poligramas, n. 31, p. 23-49, 2009. 

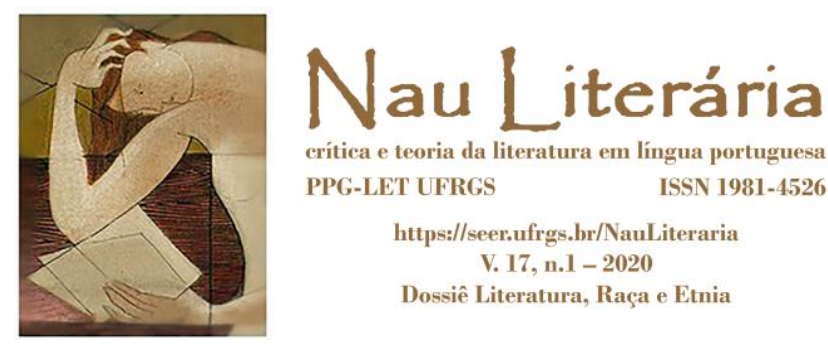

CABRAL, Danilo Cezar. Papa Doc, o ditador que tocou o terror no Haiti. Revista Super Interessante, 2018. Disponível em: <https://super.abril.com.br/mundo-estranho/papadoc-o-ditador-que-tocou-o-terror-no-haiti/>. Acesso em: 10 mar. 2020.

COLÔMBIA. Grupos étnicos - Información técnica. 2018. Disponível em: $<$ https://www.dane.gov.co/index.php/estadisticas-por-tema/demografia-ypoblacion/grupos-etnicos/informacion-tecnica>. Acesso em: 10 mar. 2020.

DANTAS, Elisalva Madruga. A negritude poética do gaúcho Oliveira Silveira. Revista de Letras, Fortaleza, v. 1/2, n. 28, p. 74-77, jan. 2006. Disponível em:

<http://www.periodicos.ufc.br/revletras/article/view/2318>. Acesso em: 06 mar. 2020.

FERRER, Ada. A sociedade escravista cubana e a Revolução Haitiana. Almanack, n. 3, p.37-53, jun. 2012. Disponível em: <http://www.scielo.br/pdf/alm/n3/2236-4633-alm03-00037.pdf>. Acesso em: 10 mar. 2020.

GONÇALVES, Ana Beatriz R. Nicolás Guillén e a negritude latino-americana. Contexto, Vitória, n. 10, p. 141-146, jan. 2003. Disponível em: <http://periodicos.ufes.br/contexto/article/view/6798>. Acesso em: 05 mar. 2020.

LARANJEIRA, Pires. A Negritude africana de língua portuguesa. Porto: Afrontamento, 1995.

LOPES, Nei. Enciclopédia Brasileira da Diáspora Africana. 4. ed. São Paulo: Selo Negro, 2011.

MARTINS, Francilene. A origem negra do tango. Revista Raça, 2017. Disponível em: https://revistaraca.com.br/a-origem-negra-do-tango/. Acesso em: 11 mar. 2020.

ROSA, Renata de Melo; PONGNON, Vogly Nahum. A República do Haiti e o processo de construção do Estado-nação. Revista Brasileira do Caribe, São Luís, v. 13, n. 26, p.461-494, jun. 2013. Disponível em:

<https://www.redalyc.org/articulo.oa?id=159128818007>. Acesso em: 10 mar. 2020.

SANTA, Julia da Silva. Intelectual Negro no Sul: A Trajetória de Oliveira Silveira. Cadernos do Lepaarq, Pelotas, v. 11, n. 22, p.283-292, jan. 2014. Disponível em: <https://periodicos.ufpel.edu.br/ojs2/index.php/lepaarq/article/download/3772/3423>. Acesso em: 10 mar. 2020.

SANTOS, Donizeth Aparecido dos. Poetas de todo o mundo. Fênix - Revista de História e Estudos Culturais, Uberlândia, v. 4, n. 2, p.1-19, abr. 2007. Disponível em: $<$ http://www.revistafenix.pro.br/PDF11/Dossie.artigo.5_Donizeth.Aparecido.dos.Santos .pdf>. Acesso em: 05 mar. 2020. 

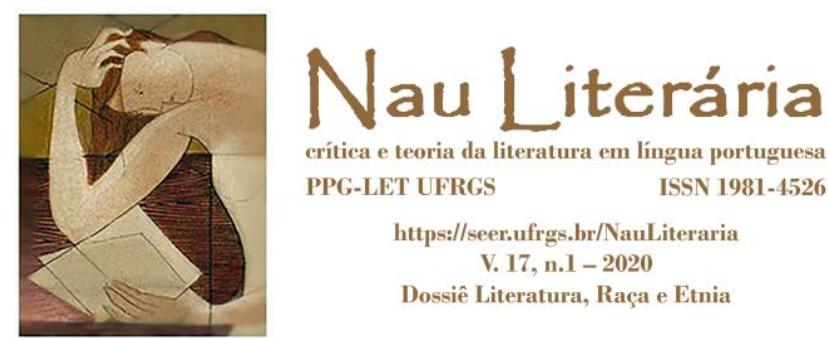

SANTOS, Jaqueline Lima. O Vodu e a Resistência Negra no Haiti. Geledés, 2010. Disponível em: <https://www.geledes.org.br/o-vodu-e-resistencia-negra-haiti/>. Acesso em: 10 mar. 2020.

SILVA, Kislana Rodrigues Ramos da. A ressignificação das propostas do panafricanismo e da negritude em Roteiro dos Tantãs, de Oliveira Silveira. In: CONGRESSO INTERNACIONAL DA ABRALIC. 13. 2013a. Disponível em:< https://editorarealize.com.br/revistas/abralicinternacional/trabalhos/Completo_Comunic acao

_oral_idinscrito_1377_a4b1a631f7be0050d244f1ed957fa227.pdf>. Acesso em: 05 mar. 2020.

Resistência e Subjetividades: marcas da africanidade e negritude na poética de José Craveirinha e Oliveira Silveira. 2013. 113 f. Dissertação (Mestrado) - Curso de Literatura e Interculturalidade, Universidade Estadual da Paraíba, Campina Grande, 2013b. Disponível em:

<http://tede.bc.uepb.edu.br/jspui/bitstream/tede/2503/2/PDF\%20$\% 20$ Kislana\%20Rodrigues\%20Ramos\%20da\%20Silva.pdf $>$. Acesso em: 05 mar. 2020.

SILVA, Liliam Ramos da. Decolonizando saberes: conceitos de literatura latinoamericana de autoria negra. In: TETTAMANZY, A. L. L.; SANTOS, C. M. Lugares de fala, lugares de escuta. Porto Alegre: Zouk, 2019. p. 115-136.

SILVEIRA, Oliveira. Obra reunida. Porto Alegre: Instituto Estadual do Livro, 2012. Organização de Ronald Augusto.

SOUZA, Barbara Oliveira. A ambígua condição negra em Cuba: Relações raciais e mobilizações coletivas antirracistas. 2015. 377 f. Tese (Doutorado) - Curso de Antropologia,

Universidade de Brasília, Brasilia, 2015. Disponível em:

<http://repositorio.unb.br/handle/10482/21204>. Acesso em: 05 mar. 2020.

TONET, Tatiana Pereira. Considerações Histórico-Literárias sobre a Revolução Escravocrata de Saint-Domingue em La Isla Bajo el Mar (2009), de Isabel Allende. Revista LHM - Literatura, História e Memória, Cascavel, v. 13, n. 21, p.305-330, jan. $2017 . \quad$ Disponível em: <http://erevista.unioeste.br/index.php/rlhm/article/view/16830/11579>. Acesso em: 06 mar. 2020. 


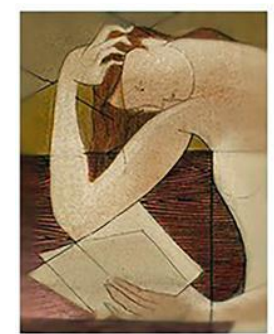

Nau Literária

erítica e teoria da literatura em língua portuguesa

PPG-LET UFRGS ISSN 1981-4526

https://seer.ufrgs.br/NauLiteraria

V. 17, n.1 - 2020

Dossiê Literatura, Raça e Etnia

YAO, Jean Arsène. Negros en Argentina: integración e identidad. Amnis, n. 2, 30 jun. 2002. Disponível em: 〈https://journals.openedition.org/amnis/183>. Acesso em: 11 mar. 2020. 